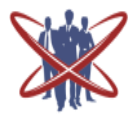

DOI: https://dx.doi.org/10.18535/ijetst/v7i4.01

\title{
The land use analysis of oil palm plantation To increase of income in east Kalimantan Province
}

\author{
Author \\ Gasim Alwi \\ Doctoral in Economics and Business Programs, Padjadjaran University \\ Faculty of Economics and Business, Bandung Indonesia
}

\begin{abstract}
The development of oil palm plantation has been playing important roles in the economic development, which in turn increasing the income of rural community in East Kalimantan. However, this development will trigger the conversion of land function from forest and farming lands to oil palm plantations. This research applies unit analysis of sub-district/village in the region of East Kalimantan Province using pixel format (1 pixel was equivalent to $1.000 \mathrm{ha}$ ) through the process of geospatial model during the research period from 2000 to 2011.

Secondary data were used in the process of regression model analysis of using OLS (Ordinary Least Square) and Probit Estimation to estimate the land use and the income of oil palm farmers. The results of model shows that (1) land use for oil palm plantation, has a significant positive correlation with variables, deforestation and the area of oil palm plantation, but the area of forest land cover has a negative correlation. The result also shows that there was a negative correlation between deforestation variable and forest variable. This was because not all of the lands used for plantation were derived from forest lands. (2) In terms of probit panel estimation model, it was found that there was a positive and significant effect of production oil palm plantation on expansion of oil palms and (3) income of households that have oil palm plantations.
\end{abstract}

Forest land use and development needs to be controlled by taking economic factor into account; otherwise, it will give a negative impact on the income of the community.

Keywords: Land use, oil palm. Sub-district/village, pixel, geospatial model, OLS (ordinary least square), Probit, DEFOR, FOR, PPSz, and income of households that have oil palm plantations.

\section{Introduction}

The potential of the agricultural sector also has a large potential to be developed and can be used as a substitute sector after oil and natural gas runs out. East Kalimantan macroeconomic indicators in 2012 showed that East Kalimantan's GRDP in 2012 each sector produced the following contributions: Agriculture Sector $6.06 \%$ more potentialy sector. Province of East Kalimantan in Indonesia, was identified as having areas that have the potential to be developed as cultivation areas such as fisheries, agriculture, tourism, industry, mining and others based on regional spatial plans. The development of agricultural and oil palm plantation investor policies has begun since the 1985s to the present in East Kalimantan Province. After the regional autonomy increased, namely in 2000 to $345,521 \mathrm{Ha}$, in 2005 to 388,623 $\mathrm{Ha}$, and Year 2010 became 428,059 $\mathrm{Ha}$ and in 2013 it had reached 944,092 Ha. We were loked in Figure 1. 


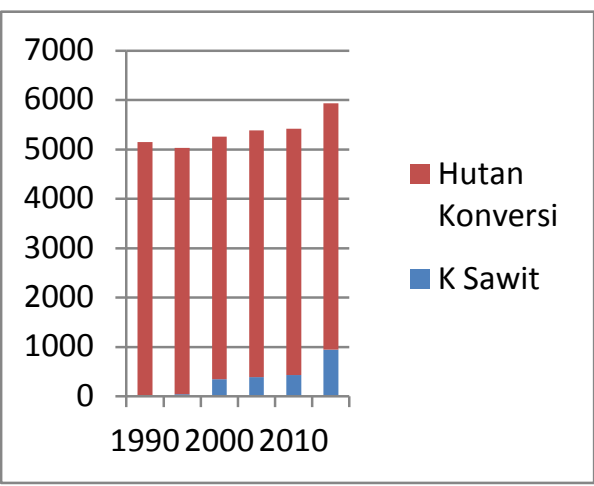

Fig 1: East Kalimantan Province Forestry Office, Indonesia processed (2014).

The Sustainable development is considered as an effort to achieve a balance including environmental, social, and regional economic improvement. The role of the oil palm plantation sub-sector in East Kalimantan Province has provided benefits in improving the welfare of the people in East Kalimantan. The multiplier effect were of plantations also increases income, employment creation and welfare. While in the other side of the development of oil palm will have greater environmental damage because it can cause greater environmental damage. So it is necessary to look at the effects caused positively and negatively, especially the use of land for oil palm plantations which have now exceeded 1 (one) million hectares more in 2015 in East Kalimantan Province in Indonesia.

\subsection{Formulation of The problem.}

The conversion of forestry land to the agriculture sector of sub-sector plantation. The resulting phenomenon results in several common problems that occur as follows:

- There is environmental damage caused by uncontrolled land use.

- Research on land use dynamic modeling in oil palm is still lacking;

- Land use change analysis on oil palm is still a static analysis approach;

- Research is needed that measures land use dynamic by looking at the dominant factors that cause oil palm land in East Kalimantan.
- Does the development of the palm oil subsector contribute positively to the education sector and the quality of life of the people.

- Based on the description and explanation of the location of the research object, the specific problems in the study can be identified as follows:

- How is the influence of palm oil production, land use and the value of the sale price of fresh fruit bunches (HTS) in the Province of East Kalimantan.

- What is the double effect of the existence of oil palm plantations on the income of oil palm farmer households in the Province of East Kalimantan.

- What is the double effect of the existence of oil palm plantations on the economic development of the Province in East Kalimantan.

- What is the effect of the development of oil palm plantations on land use in East Kalimantan Province.

\subsection{Research purposes}

By paying attention to the phenomena and problems that will be examined, explained, studied in this study it is necessary to:

a) See the effect of forest land use, on land use (land use), especially oil palm plantations in the Province of East Kalimantan.

b) It's the knowing the effect of oil palm plantations on the income of oil palm growers in the province of East Kalimantan.

\subsection{Sustainability Criteria and development economics}

According to Perman R (2003) there are 2 (two) things that need to be considered in paying attention to sustainability, namely:

a) Sustainability is paying attention to where the consumption of utilities that does not continue to decline over time.

b) Sustainability is one of the ways in which resource management maintains future production opportunities Economic 
development and economic growth are both interconnected economic phenomena.

\subsection{Theory of land use (land use change theory).}

Soil conservation in the broadest sense is the use of each parcel of land in accordance with the capability of the land and functioning properly so that no soil damage occurs. Understanding Tana Guna Lahan or Land use can be interpreted as; "Land use regulation (governance = arrangement)". In land use, it is also discussed not only about the surface of the earth on land, but also about the use of the earth in water/oceans.

The government promotes the development of these plantations in order to reduce poverty, consume food and renewable energy. This study is more about the use of land (land use) of oil palm from all available land in the area of oil palm producers

\subsection{Empirical Study.}

This research refers to research conducted by:
Research conducted by Irwin E.G and Geoghegan. J (2016), namely; with the title: "Developing spatially explicit economic models of land use change", the model is estimated using observations of actual land use conversions and then used to predict the probability of development of each cell for future development rounds and is very significant, while the output of this type of model this is a probability map

Research conducted by: Tepe E, and Guldmann J.M (2017).

Tepe E, and Guldmann JM, conducted a study with the title of the research: "Spatial and temporal modeling of parcel-level land dynamics", on land use at certain times with the STARM model (spatio-temporal autoregressive model), this model is related to space, time, area, impact, parcel, and the surrounding area.

\subsection{Framework}

Adjust to the previous frame of mind that already exists as shown in Figure 2.

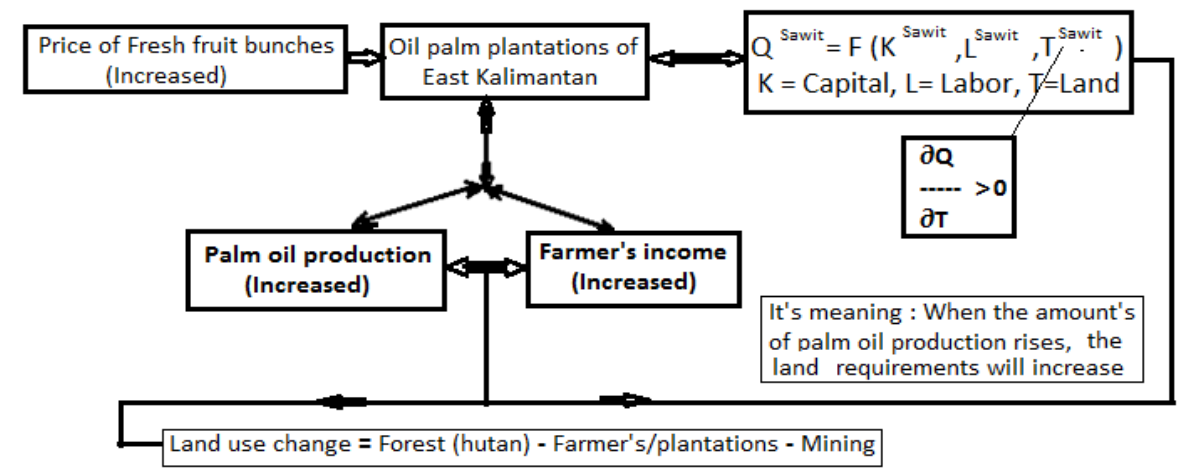

Fig 2: Framework

Data on land use conversion of oil palm plantations in East Kalimantan Province is very difficult to obtain along with location coordinates based on land use permits per region. After the data is obtained in the form of raster then it is onscreen digitizing which is converted to spatial elements in vector format to get more specific / smallest data per oil palm farmer. In order to obtain farmer land use data in pixel format (1 pixel 1,000 ha), this data facilitates the measurement of land use of oil palm plantations.
The resulting production is very much determined by the price of fresh fruit bunches, so that it greatly influences the income and land use of oil palm plantations from time to time.

The price of oil palm fruit bunches also influences the income and investment of oil palm plantations, oil palm plantation labor and land use. Land use change itself consists of forestry, agriculture / plantation and mining land (coal / gold mining), meaning that when the amount of palm oil production rises the land demand will increase, 
the need for $\mathrm{T}=$ land use of palm oil, where Q X $(1 / \mathrm{K}, 1 / \mathrm{L})$ so that it will be seen, demand for land.

Expansion will occur if the income of oil palm growers increases, this is highly dependent on the increase in the price of TBS (Fresh Fruit Bunches), while the yield will be a measure of the selling price of oil palm fruit. Increased income of farmers will influence and generate interest or desire to change land use, such as dry land, wet or rainfed agricultural land and other plantations to be used as oil palm plantations

\subsection{Research Hypothesis}

The Oil palm plantations with their productivity function have an impact on the allocation of resources which then leads to increased productivity, farmer income, increased economic growth and the emergence of land use problems:

a) Oil palm plantations positively affect land use (land use) for the conversion of functions or conversion of forestry land in East Kalimantan Province.

b) Oil palm plantations have a positive effect on the income of oil palm growers in East Kalimantan Province

\section{Research methods}

The research method used cannot be separated from the paradigm and research approach. The scope of the research study data required is data relating to the income of becoming an oil palm farmer, data relating to production, land cover area and area of oil palm plantations.

\subsection{The data collection and estimation methods.}

In this case the method used for this research also uses the method of library research, namely research using secondary data to see the symptoms and facts that occur, which will be a picture of the pattern of relationships, farmer income and land use and the environment and factors other factors that influenced it for analysis in the province of East Kalimantan for the period 2000-2011. Where a grid with a size of 1,000 ha / pixel is overlaid against the land use map and its administrative boundary reaches the village level. The advantage of using this grid cell cutting technique is that we can see land use change up to the limit of the smallest administrative unit, village, where available aggregation data is usually unable to analyze land changes dynamically to the village level. As a small illustration, to find out the number of pixels in 1 village, in the case of Tanjung Harapan Sub district, Paser Regency, East Kalimantan Province by using the above methods seen in table .1.

Table 1. Village Area Measurement Using Pixels

\begin{tabular}{|l|c|c|c|}
\hline \multirow{4}{*}{ Regency } & $\begin{array}{c}\text { Sub- } \\
\text { district }\end{array}$ & Village & $\begin{array}{c}\text { Number of } \\
\text { Pixel }\end{array}$ \\
\hline \multirow{4}{*}{ PASER } & \multirow{3}{*}{$\begin{array}{c}\text { Tanjung } \\
\text { harapan }\end{array}$} & Labuang kalo & 40 \\
\cline { 3 - 4 } & & Random & 110 \\
\cline { 3 - 4 } & & Selengot & 50 \\
\cline { 3 - 4 } & & Tanjung aru & 140 \\
\cline { 3 - 4 } & & Tunas Keladen & 140 \\
\hline & & Total & 480 \\
\hline
\end{tabular}

Source: Calculation Results, 2018

We can calculate land use change for each village has a land of 140 pixels where 1 pixel $=1,000$ ha. This means that the area of the village of Tunes Keladen has an area of 140 pixels $\times 1000$ ha = 140,000 ha. The land area of Selengot Village = 50 pixels $x 1000$ ha $=50,000$ ha. To justify how accurate this pixel approach is, we compare the amount of land area as follows:

Table 2. Area Validation of East Kalimantan Province with Processed Data Results Using Pixel Units

\begin{tabular}{|c|c|c|c|c|c|c|c|}
\hline 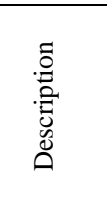 & 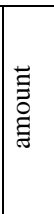 & 站 & 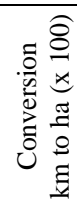 & $\begin{array}{l}\infty \\
. \\
\text { 혀 }\end{array}$ & 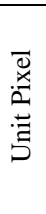 & unit & 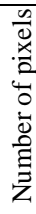 \\
\hline 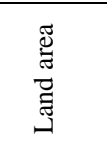 & 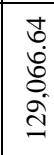 & 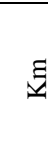 & 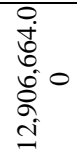 & ha & $\dot{8}$ & 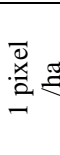 & 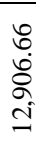 \\
\hline $\begin{array}{c}\text { the } \\
\text { calculate } \\
\mathrm{d} \text { data of } \\
\text { pixel } \\
\text { area }\end{array}$ & 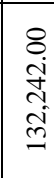 & 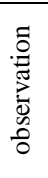 & - & 10 & $\begin{array}{c}\text { ye } \\
\text { ar } \\
\text { s }\end{array}$ & 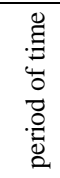 & $\begin{array}{l}\stackrel{N}{N} \\
\stackrel{\sim}{+} \\
\stackrel{-}{-}\end{array}$ \\
\hline & & & & & & & : \\
\hline
\end{tabular}

Source: Processed Data Results, 2018. 
In the table above, it can be seen that the number of pixels processed data 13,224.20>12,906.66 means that the data layer used in the data layer. The curve into 317 pixels squares. Because the pixel data characteristics are the same as vector, it will facilitate land conversion that occurs on the digitization map, especially for oil palm farmers in the village / sub-district area. Polygon grid cell (pixel) in the data analysis is then translated using a probability model developed to calculate the likelihood that one pixel will change from nonpalm oil to palm oil. Geo Processing software to convert data from land use change into pixels using Quantum Geo Information System (QGIS) software. Where is as administrative as boundary data is obtained from village administrative boundary data from the Central Statistics Agency. Data on land use change were obtained from the Forestry Service, the Plantation Service and Development and Planning Office of East Kalimantan Province and other library materials

\section{Research Design}

This research uses descriptive and quantitative approaches. This study uses panel data that has advantages namely; First, the number of observations is greater and has greater variability as well as can reduce the collinearity between explanatory variables. Second, the data panel can provide more information. Third, panel data / panel data can provide better resolution in dynamic change inference compared to cross section data. This research is also supported by Spatial Geo by using Quantum Geo Information Spatial (QGIS) for mapping data and land use including forestry and agricultural land cover in East Kalimantan Province on the environmental side of land use. The use of pixel data $=$ raster data per region converted by screen digitizing to get spatial elements to digital vectors from 2000 to 2011. Vector data is a graphic representation of spatial data that has accuracy in the representation of boundary points in a straight line as well as position accuracy because the structure of vector data involves pointers in the form of nodes / points.

\subsection{Operational Variables}

The Production is a quantitative measure that describes the development activities of production (on farm), especially oil palm in a certain stage compared to the previous year.

Table 3. Operational Variables and their Measurements

\begin{tabular}{|c|c|c|c|c|c|}
\hline $\begin{array}{l}\mathrm{N} \\
\mathrm{o}\end{array}$ & 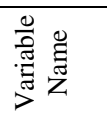 & 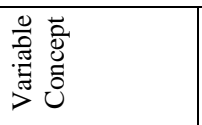 & 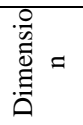 & 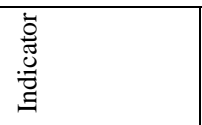 & $\begin{array}{l}\frac{0}{\tilde{J}} \\
\tilde{n}\end{array}$ \\
\hline 1 & 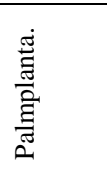 & 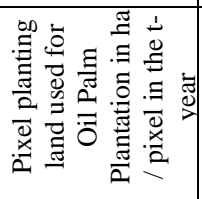 & $\begin{array}{l}\overline{\vec{v}} \\
\stackrel{x}{a}\end{array}$ & 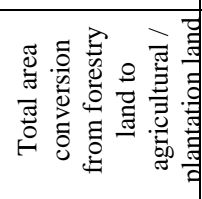 & 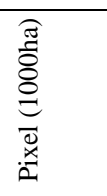 \\
\hline 2 & $\begin{array}{l}\stackrel{\tilde{0}}{\amalg} \\
0\end{array}$ & 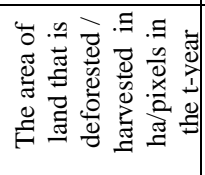 & $\begin{array}{l}\overline{\vec{v}} \\
\stackrel{x}{0}\end{array}$ & 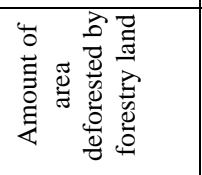 & 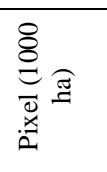 \\
\hline 3 & 官 & 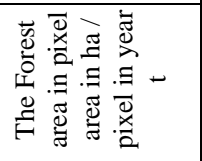 & $\begin{array}{l}\overline{\mathbb{v}} \\
\stackrel{x}{0}\end{array}$ & 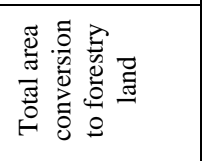 & 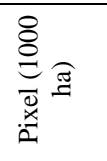 \\
\hline 6 & 古 & 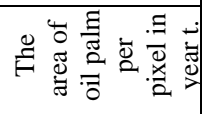 & $\begin{array}{l}\overline{\vec{v}} \\
\stackrel{x}{0}\end{array}$ & 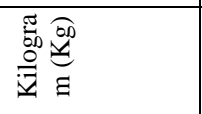 & 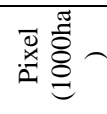 \\
\hline 7 & 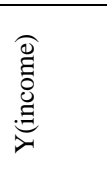 & 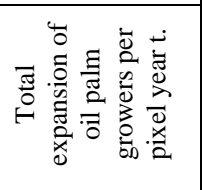 & 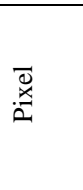 & 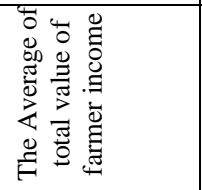 & 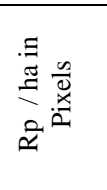 \\
\hline 8 & 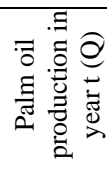 & 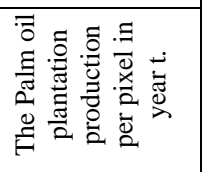 & $\begin{array}{l}\overline{\vec{v}} \\
\stackrel{x}{0}\end{array}$ & 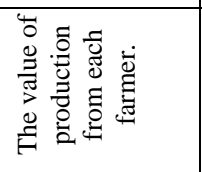 & 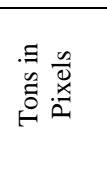 \\
\hline 9 & 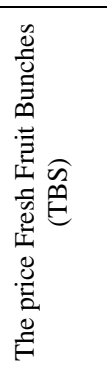 & 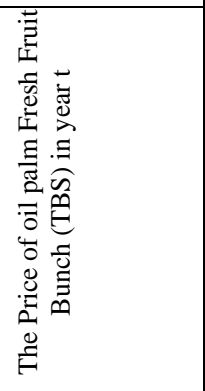 & 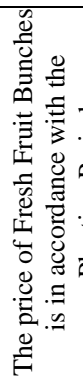 & 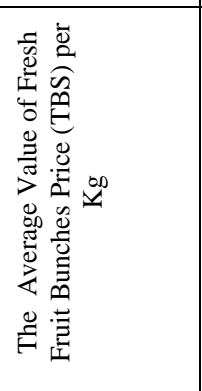 & $\begin{array}{l}\stackrel{00}{a} \\
\frac{a}{a}\end{array}$ \\
\hline
\end{tabular}

Data source: processed (2017)

The contribution of agricultural development in the palm oil affects the income of oil palm farmers. The effect of the age of an oil palm plant affects the quantity and quality of production per hectare each year. We will see in the table 3 . 


\subsection{Analysis Model, Model Test Design, Feasibility Test Design, Hypothesis Test Model and Design.}

\subsubsection{Analysis Model}

The testing is analysis model of the impact of oil palm plantations on land use and household income of oil palm farmers in East Kalimantan Province. The results of the analysis test will be influential and can be measured by several indicators. Hypothesis testing uses quantitative analysis techniques using panel data which is a combination of time series data for 2000-2011 and cross section data in East Kalimantan Province, using geo spatial data with Quantum Geo Information Spatial (Q-GIS) applications and processing with stata applications. Processing with Stata application is able to display analysis graphically, tables and analysis between variables. In analysis with econometrics, combining times series data with cross sections known as panel data can result in problems in the estimation process, these problems can be interruptions between time, between individuals or both (Gujarati: 650). The OLS (Ordinary Least Square) Regression model developed from David Wheler, Dan Hammer, Robin Kraft, Susmita Dasgupta, and Brian Blankespoor (2011), and Okon.U, E. C. Okorji.EC) (2014), and the probit panel estimation model from Irwin and Geoghegan (2016) and Tepe E, and Guldmann J.M (2017) research. Oil palm plantations are very influential on the use of specific land in land cover and conservation of forestry land to oil palm plantations as well as increased income of oil palm farmers. Based on the framework of thought and previous research, we developed an econometric model that is used in 3 (three) equation models, as follows:

Model 1: Land use model - this model is to see changes in land use change, the extent of land use changes in each pixel. This model was obtained from Tepe-Guldman (2017), where the initial model was from

(1) $\mathrm{LUC}=\mathrm{dL}$ Forest $-\mathrm{dL}$ Agric $-\mathrm{dL}$ Other Use.

Where LUC is the same as Land Use Change, agricultural land use function (dL Agric), and other land use functions (dL Other Use). So from the above equation we can simplify the equation for the function of oil palm plantations

(2) Lpalm $=$ dLForest - dL Agric - dL Other Use.

deforesation $=-(\mathrm{dL}$ Agric $+\mathrm{dL}$ Other Use $)$ while Lpalm is part of the deforesation so - $\mathrm{dL}$ palm $=-(\mathrm{dL}$ Agric $+\mathrm{dL}$ Other Use $)$, then the coefficient $\mathrm{dL}$ palm $=\mathrm{dL}$ defores, while $\mathrm{dl}$ Forest = -

This model uses ols regression (ordinary least square) with pixel data developed as shown below:

$$
\begin{aligned}
& \text { Palmplanta }_{\mathrm{p}, \mathrm{t}}=\beta_{0}+\beta_{1} \text { DEFOR }_{\mathrm{p}, \mathrm{t}}+\boldsymbol{\beta}_{\mathbf{2}} \mathrm{FOR}_{\mathrm{p}, \mathrm{t}}+\boldsymbol{\beta}_{\mathbf{3}} \\
& \text { PPSz }_{\mathrm{p}, \mathrm{t}}+\boldsymbol{\varepsilon}_{\mathrm{pt}}^{\mathbf{1}} \ldots \ldots \ldots \ldots \ldots \ldots \ldots \ldots \ldots \ldots \ldots \ldots \ldots \ldots \ldots \ldots \ldots \ldots \ldots \ldots \ldots \ldots \ldots
\end{aligned}
$$

Where :

Palmplanta $p, t=$ the use of oil palm plantations per pixel in year $\mathrm{t}$.

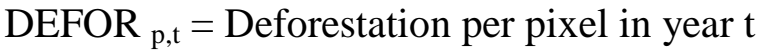

$\mathrm{FOR}_{\mathrm{p}, \mathrm{t}}=$ Forest cover area per pixel in area $\mathrm{i}$ year $\mathrm{t}$.

$\mathrm{PPSz}_{\mathrm{p}, \mathrm{t}} \quad=$ Size of oil palm plantation area per pixel in year $\mathrm{t}$

$\boldsymbol{\beta}_{0} \quad=$ constant or interception.

$\boldsymbol{\beta}_{1 . .5}=$ the regression coefficient of the land use model.

p $\quad=\operatorname{pixel}(1$ pixel $=1000$ hectares)

t $=$ Year $\mathrm{t}(\mathrm{t}=2000-2011)$

$\varepsilon^{1} \quad=$ confounding element

The model 2 as shown below:

The answered of effect of oil palm plantations on household income. We use these two models: Estimating changes in the improvement of oil palm plantations with dummy size (if 1 pixel is planted with oil palm, and 0 is not planted with oil palm) using the land demand equation (behavior demand equation (behavioral equation) in Tepe and Guldman, 2017); $\mathrm{L}_{\mathrm{pt}}=\mathrm{f}\left(\mathrm{Q}_{\mathrm{pt}}\right)$, demand for land can be defined that 
(1) (Model 2) $\mathrm{L}_{\mathrm{pt}}=\mathrm{f}\left(\mathrm{Q}_{\mathrm{pt}}\right)$ which means that the general model of land demand is influenced by production. Furthermore, to be more specific, the Lpt is proxied by the use of oil palm plantations using the following formula

\section{Lpt $^{*}=\mathbf{f}($ UTPSput $\times$ PTBSut $)$}

where $\mathrm{L}_{\mathrm{pt}}=$ Pixel Area planted by Oil Palm Plantation = 1; Not palm = 0; and $\mathrm{Q}_{\mathrm{pt}}=$ Number of Production in pixels planted with palm = Oil Palm Land with Planting Age Oil Palm Plantation in the pixel area (UTPSput) $x$ (PTBSut) price of fresh fruit bunches according to the age of planting (u) in the t-year.

Model 2: Econometrics.

$(\mathrm{PEXP}=1 / 0)=\delta 0+\delta 1(\mathrm{PTBSt}$ X QPO p,t $)$

$+\varepsilon 2 p, t$

Where :

$\mathrm{P}(\mathrm{PEXP}=1 / 0) \quad \mathrm{p}, \mathrm{t}=$ Dummy expansion of oil palm planting per pixel in year $t$. in the form of 1 if planted with oil palm and 0 if not planted with oil palm.

$\mathrm{Q}_{\mathrm{p}, \mathrm{t}}^{\mathrm{PO}}=$ Production of oil palm plantations per pixel in year $\mathrm{t}$

$\mathrm{P}_{, \mathrm{t}}^{\mathrm{TBS}}=$ Price of fresh fruit bunches per $\mathrm{kg}$ in year $t$.

$\boldsymbol{\delta}_{\mathbf{0}} \quad=$ constant or intercept.

$\boldsymbol{\delta}_{\mathbf{1}}=$ Probit coefficient of oil palm farmer income models

p $\quad=\operatorname{pixel}(1 \mathrm{p}=200$ hectares $)$

t $\quad=$ Year $\mathrm{t}(\mathrm{t}=2000-2011)$

$\varepsilon^{2}=$ confounding element

Prediction of Land Expansion from equation (3.2) becomes

$\mathrm{P}(\mathrm{EXP})^{*}=\delta_{0}+\delta_{1}\left(\mathrm{P}_{\mathbf{t}}^{\mathrm{TBS}} \mathrm{X} \mathrm{Q}_{\mathrm{p}, \mathrm{t}}^{\mathrm{PO}}\right)+\varepsilon_{\mathrm{p}, \cdot \cdot \cdot}^{2}$.

where $\mathrm{P}(\mathrm{EXP}) *=$ Probability of land conversion due to oil palm production and the development of Fresh Fruit Bunches (PTBSpt) and the amount of production according to the age of planting (QPOpt).
(Model 3) Estimating changes in land use to community income Ypt $=\mathrm{f}$ (Lpt) where the prediction of land use change due to rising FFB prices and Land Expansion will increase income where Lpt is obtained from $\mathrm{P}(\mathrm{EXP}) *$, then $\mathrm{L}_{\mathbf{p t}}=$ $\mathrm{P}(\mathrm{EXP}) *$ so that

(3) $\mathbf{Y}_{\mathrm{pt}}=\boldsymbol{f}\left(\mathrm{P}\left(\mathrm{EXP}_{\mathrm{pt}}\right) *\right)+\mathrm{e}$

Where; Ypt $=$ Community income at each pixel in the period $\mathrm{t}$, and $\mathrm{Lpt} *$ is the result of prediction of the possibility of oil palm expansion in model 2. Hypothesis: $b 1>0$

$$
\mathrm{Ypt}=\mathrm{a}+\mathrm{b} 1 \mathrm{P}\left(\mathrm{EXP}_{\mathrm{pt}}\right)^{*}+\mathbf{e}
$$

\subsubsection{Model Identification.}

Identify the model by identifying data and information in the field, by processing it through the Quantum Geo Spatial Information System (QGIS), as shown in Table 2, from that information can be processed by regression analysis.

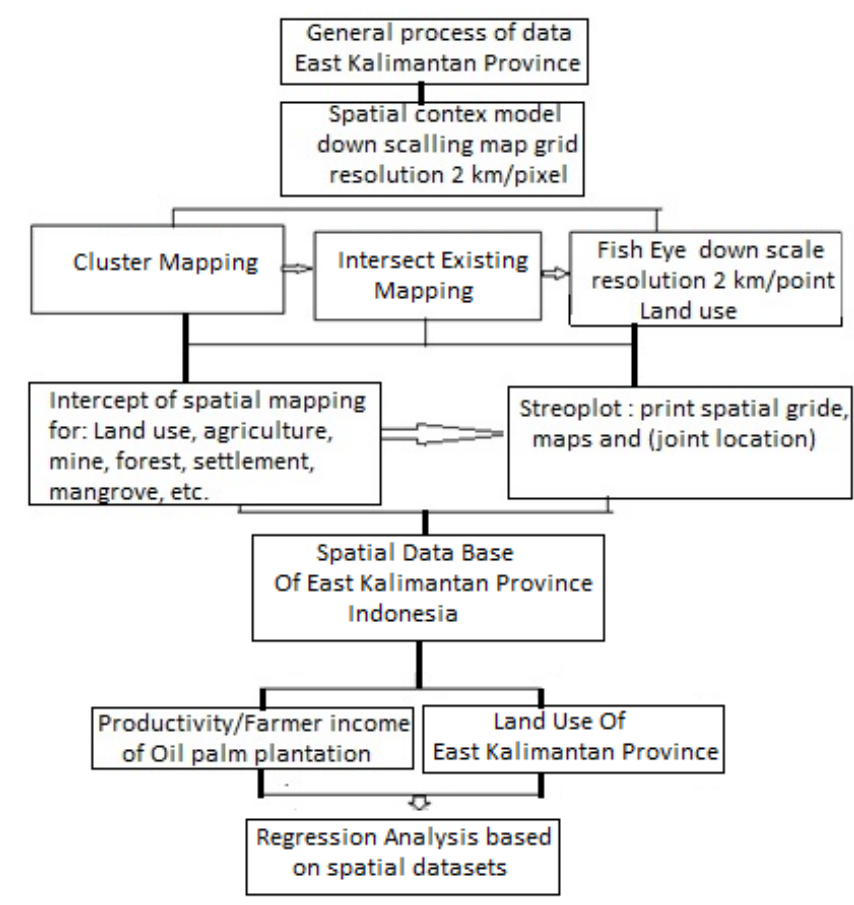

Source: Eko Budiyanto (2016), p. 50-218. (modification).

Fig 3: The Geo Spatial Information on Context Model East Kalimantan Province (2011). 


\subsection{The Geo Spatial Information on contex Model od East Kalimantan Province (2011).}

The process of forestry coordinate position data at the location of the Province of East Kalimantan, which was initially divided into 2 (two) provinces so that it is quite difficult because they have to separate the location coordinates of each province per village, so that it is obtained specifically the position of the Province of East Kalimantan. After that, intersect per point (pixel or picture element) of locations per 1000 (one thousand) hectares will be carried out, which in turn is obtained land use data / location of each land cover according to permits or legal permits for the use of forestry land, plantations, dwelling, protected forests , primary forests, swamps, mangrove forests, dry land forests and other locations. After data is obtained on land use as a whole, new data is specifically identified relating to the location of oil palm plantations in accordance with permits granted by the government from 2000 to 2011 or the deadline of licensing or moratorium regulations for new licenses not to be issued except to increase licensing status / location permit / right to operate except to continue the existing licensing process. Panel data from the results of processing with the Quantum Geo Information System (Q-GIS) application is transferred to the STATA 15.1 application for processing in the context of research for oil palm plantations and land use and the environment. This estate data analysis uses cluster data which is a technique with multivariate analysis which is an observation in the data set, with a large enough sample data will represent the structure of the model. In using panel data that is combining cross-time data (times series) with cross-space data (cross-section), it has advantages (Widarjono, 2005: 253-254), (Gujarati, 2003: 637-638), namely:

This study uses panel data that has advantages namely; First, the number of observations is greater and has greater variability as well as can reduce the colinierity between explanatory variables. Second, the data panel can provide more information. Third, panel data can provide better resolution in inference of dynamic changes compared to cross section data. This research is also supported by Spatial Geo by using Quantum Geo Information Spatial (QGIS) for land use mapping data including forestry and agricultural land cover in East Kalimantan Province, regency, sub-district / village area with pixel size or representation of the smallest image/point/density elements can be calculated whereas in this study 1 pixel with a size of 1000 hectares, so the aggregation is not biased.

\subsection{The Enables learnins of complex behavioral models.}

In this study, the authors used an OLS regression model (ordinary least square) and logit or probit regression models, with a total data of 132,420, with a pixel size in East Kalimantan in Indonesia. The basic assumption is logit/probit regression, where the dependent variable is normally distributed which is a proxy for the continuous normal distribution. To test the regression model can be done with the Ramsey test, whether the model has been specified correctly or not there (specification error), if the probability $(\mathbf{P})<\mathbf{0 . 0 5}$ and calculated $\mathbf{F}$ arithmetic $<\mathbf{F}$ table then multiple regression does not occur specification error, but vice versa if $\mathbf{F}$ arithmetic $>F$ table then specification error occurs in multiple regression. Checking the model is to see which estimates are best to be precise and if there are any deviations. Then try the deviations as small as possible.

\subsubsection{Multicolinearity test.}

In the probit regression model it is assumed that it does not make the loading of linear dependency relationships between independent variables, the way the model is interpreted by looking at the generated Pseudo R2, so we see the significance of each variable with each variable. Multicolinearity can be tested using VIF to test interactions, where if the VIF value produced is all variables $>5$ and the tolerance value $<0.20$, then there is multicolinearity in the model. VIF value can also be calculated manually using the formula which is as follows: 


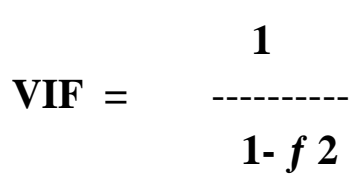

1

Tolerance $=\mathbf{1}-\boldsymbol{f} \mathbf{2}$ or $=\quad \begin{array}{r}------- \\ \text { VIF }\end{array}$

Where: $f 2=$ effect size

You can also use the Spearman test to see the matrix relationship between variables.

\subsubsection{Homocedasticity test.}

Residual errors in the regression model must be constant / fixed, so that variable predictors and variants of residuals must be constant or not exceed the estimated distance limit of the dependent variable. The various values of the predictor and conditional variables should be around the regression line in the population. Some tests can be done one of them with szoeter test and imtest estate test or decomposition of cameron \& trivedi's to see the model whether there is heterokedastisity in the model. If This is it necessary to transform and the results of the transformation must be $>0.05$. When If abnormalities occur from the previous data, then data transformation must be carried out using another analysis method, Quantile regression with STATA 15.

\section{Result and Discussion}

\subsection{Description of Research Object.}

This research variable has two dependent variables namely: Production and Land Use and nine independent variables namely : Land use.

Land Use is Deforestation, forest land cover area, natural forest, natural forest felling/deforestation, area of oil palm land and settlement as well as for production that has an effect on; Income of Oil Palm Farmers and Fresh Fruit Bunch (TBS) Prices.

The Data number of investments of Plantations in East Kalimantan, namely: in Berau Regency there are a number of 50 companies, Kutai Timur Regency there are 77 companies, Kutai Kartanegara Regency there are 62 companies,
Kutai Barat Regency there are 43 Companies, Mahakam Ulu Regency there are 15 companies, Penajam Paser Utara Regency has 14 companies, Paser Regency there are 39 companies, Samarinda City there is 1 company, in total there are 301 companies with location permits covering an area of 3,313,956.96 ha, which already use rights with an area of $1,057,616$. ha. We used the farmer exchange rate (NTP), which is one indicator to see the purchasing power of farmers in rural areas, also shows the purchasing power of farmers (term of trade) of agricultural products with goods and services consumed as well as for their agricultural production costs.

\subsection{Land Deforestation}

Deforestation is the process of removing forests or natural forests by carrying out deforestation / logging to take wood or other elements by changing the allotment of forest land into nonforest.

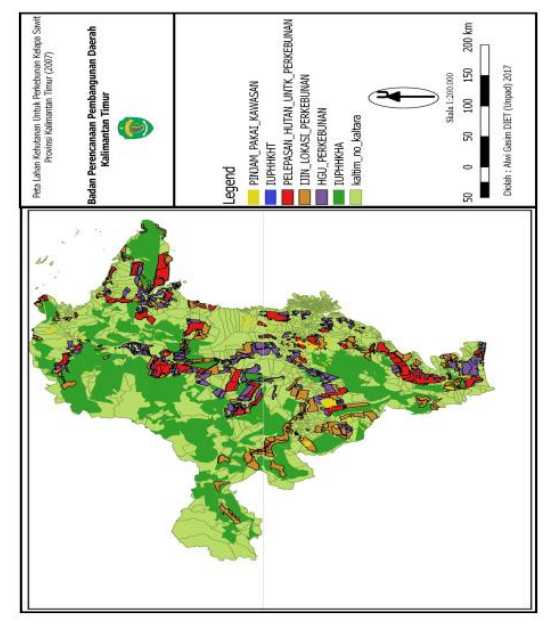

Fig 4: The land use of East Kalimantan Province Indonesia (2011) (processed)

The results of processing the data into a matrix (attached) it is clear and significant that the existence of oil palm plantations greatly affects the availability of forestry land use, this is also made clear by the regression analysis of land use permits for oil palm plantations with land deforestation (shown in the attached data processing (Land Deforestation Matrix Forestry Year 2000 - 2010 in East Kalimantan Province)). 
The data is processed for ten years because from before 2000 to 2011 in fig 4 .

The period between 2000 and 2011 was the issuance period of land use permits, especially for oil palm plantations, thus greatly affecting the availability of land for the forestry environment it. The area is growing year by year, so that changes in the use of forestry land for oil palm plantations. The existence of a moratorium policy and a polemic on the ratification of the spatial plan of East Kalimantan Province were ratified late, this has contributed to the submission of new licenses and needs to be approved since 2007. The moratorium it's self has the aim to improve the governance of palm oil commodities, namely; environmental improvement, licensing control, increasing productivity, fostering farmers, developing downstream industries, reducing emissions from deforestation and forest degradation.

Table 4. Palm Oil Production Data in East Kalimantan Province Indonesia

\begin{tabular}{|l|c|cc|c|}
\hline No & Year & \multicolumn{2}{|c|}{$\begin{array}{c}\text { Production } \\
\text { tone }(000.000)\end{array}$} & $\begin{array}{c}\text { Wide area } \\
(\mathrm{Ha})(000)\end{array}$ \\
\hline 1 & 2010 & $2,9$. & tone & 563,4 \\
\hline 2 & 2011 & 4 & tone & 716,3 \\
\hline 3 & 2012 & 5,2 & tone & 824,4 \\
\hline 4 & 2013 & 6,9 & tone & 944,8 \\
\hline 5 & 2014 & 9,6 & tone & 1.000 \\
\hline 6 & 2015 & 11,2 & tone & 1.090 \\
\hline
\end{tabular}

Data Source: East Kalimantan Province Plantation Service (20016).

The oil palm production in Indonesia according to the age of the plant itself, it is divided into 4 (four) stages if the plants produce as shown in table 5 .

Table 5 The Average Production of Palm Oil Based on Plant Age in the province of East Kalimantan (Indonesia)

\begin{tabular}{|c|c|c|c|}
\hline No & $\begin{array}{c}\text { Plant age/ } \\
\text { year }\end{array}$ & $\begin{array}{c}\text { Production / } \\
\text { Ha / year }\end{array}$ & Information \\
\hline 1 & 3 & 18,565 ton & the first fruit \\
\hline 2 & 4 & 20,958 ton & - \\
\hline 3 & 5 & 24,658 ton & - \\
\hline 4 & $>5$ & 30,361 ton & - \\
\hline
\end{tabular}

Data Source : Plantation Office of East Kalimantan Province (processed (2017))

\subsection{The Palm Oil Farmer Income.}

The observational data as many as 132,420 pixels into a data group, then the data is intercepted from the Quantum Geo information System (Q-GIS) into points measured every 1 (one) pixel point of 1,000 ha or $1 \mathrm{~km}$ wide. After that, it can only measure the extent of land use (oil palm) of oil palm plantations that produce fresh fruit bunches (TBS) then the production is sold to palm oil processing plants. Fresh fruit bunches (TBS) are sold according to the value of the price (at that time) and the value of the yield. We are assume that if the income of the farming community increases, it will trigger land expansion so that land use will increase in the sense that unproductive land becomes productive land. If the production results increase will result in the expansion of agricultural / plantation land or there will be a change of other land functions for oil palm plantations.

\section{Variable Description}

We were the used of land use analysis using pixel calculations, the advantages and this approach, can determine the transfer of land functions to the smallest administrative boundary analysis unit, namely the village.

For statistical descriptions can be seen in the table 6.

Table 6. The Descriptive Variable Statistics (table used)

\begin{tabular}{|c|c|c|c|c|c|}
\hline 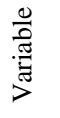 & ठै & 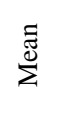 & 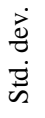 & $\sum^{\Xi}$ & $\sum_{\Sigma}^{\approx}$ \\
\hline 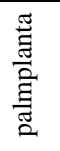 & 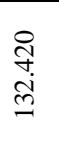 & $\begin{array}{l}\infty \\
\stackrel{0}{0} \\
\stackrel{0}{0}\end{array}$ & $\begin{array}{l}\infty \\
\vec{b} \\
8 \\
8\end{array}$ & 0 & §ু \\
\hline 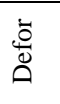 & $\begin{array}{l}\text { Iิ } \\
\text { तi } \\
\end{array}$ & 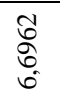 & 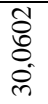 & 0 & $\begin{array}{l}n \\
n \\
n \\
\infty \\
\infty\end{array}$ \\
\hline 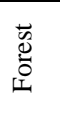 & 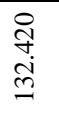 & $\begin{array}{l}\hat{q} \\
\tilde{w} \\
\infty \\
\infty\end{array}$ & $\begin{array}{l}\hat{\sigma} \\
\hat{0} \\
\text { i } \\
-\end{array}$ & in & ৪ু \\
\hline 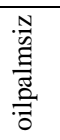 & 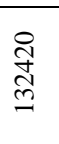 & 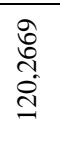 & $\begin{array}{l}\stackrel{\hat{m}}{\mathrm{~m}} \\
\stackrel{\text { }}{*}\end{array}$ & 0 & $\begin{array}{l}\text { ñ } \\
\text { îे }\end{array}$ \\
\hline
\end{tabular}

Source: Data processed 2018. 
Palmplanta $=$ the amount of oil palm allowed in one pixel area where 1 pixel $=1000$ ha. DEFOR is deforestation (land clearing) caused by the conversion of forest land to other land used for mining or agricultural land in an area of 1 pixel. FOREST is a forest land in the form of protected forest land and industrial forest and mangrove forest in an area of 1 pixel.

The total number of pixels in this dissertation observation is 132,420 pixels that are dynamically identified. For palmplanta it means that for each pixel the average use of land for oil palm plantations planted is $9.08 \mathrm{ha} / 1$ pixel. The DEFOR variable is the amount of land that has been deforested in 1 pixel which is 6.69 ha, meaning that in the relevant pixel, the average deforestation is 6.69 ha. For FOREST, this means that in an average of 1 pixel they have a forest area of 825.43 ha. While oilpalmsiz is the size of an oil palm plantation where on average in 1 pixel there are 120.26 ha of oil palm plantations.

\subsection{The Estimation Model}

\section{Land use.}

The results of processing from the land use of oil palm plantations in the province of East Kalimantan as shown in table 7.

Table. 7. Land Use Change Model (Model 1):

\begin{tabular}{lc}
\hline VARIABLES & $\begin{array}{c}\text { Land area of oil palm } \\
\text { plantations planted } \\
\text { (in hectares) }\end{array}$ \\
\hline Deforestation (ha) & $0,0407 * * *$ \\
$(0,0062)$ \\
Forest Land (ha) & $-0,126 * * *$ \\
& $(0,00143)$ \\
Size of Oil Palm & $0,0324 * * *$ \\
Plantation (ha) & $(0,00068)$ \\
Constant & $109,2 * * *$ \\
& $(1,219)$ \\
Observations & 132.420 \\
R-squared & 0,090 \\
\hline Standard errors in parentheses \\
$* * *$ p $<0.01, * * \mathrm{p}<0.05, * \mathrm{p}<0.1$
\end{tabular}

Exceeding deforestation (land clearing) by 40.69 Ha means $99 \%$ significantly higher compared to the planting area of oil palm plantations of 1 pixel (1000 ha). Every 1 pixel increase (1000 ha) will significantly increase the area of oil palm plantations that need more than $0.12636 \times 1000$ ha $=126$ ha. The addition of the size (size) of oil palm plantations by $32.41 \mathrm{Ha}(0.03241 \times 1000 \mathrm{ha})$ has a significant effect on $99 \%$ of the need for plantation land area of 1 pixel (1000 ha).

Table. 8. The effect of Oil Palm Plantation Production on Oil Palm Plantation Expansion

(Model 2): Probit Panel Estimation Table

\begin{tabular}{lc}
\hline VARIABLES & $\begin{array}{c}\text { Dummy of Oil } \\
\text { Palm Plantation } \\
\text { Expansion }\end{array}$ \\
\hline Value of Palm Oil & $0.192 * * *$ \\
Production (in IDR Million) & $(0.00969)$ \\
A constant & $-15.13 * * *$ \\
& $(0.262)$ \\
Number of Obs. in Pixels & 132.420 \\
Number of cell code & 13,242 \\
\hline nard errors in parentheses & \\
$\mathrm{p}<0.01, * * \mathrm{p}<0.05, * \mathrm{p}<0.1$ &
\end{tabular}

When we are interpreting the probit panel model above, it should be noted that the calculation of production values is calculated using the formula: (1) Value of Oil Palm Production (in IDR Million) $=($ TBS $)$ Fresh Fruit Bunch Prices in Accordance with Production Age of Palm Oil Plantation $/ \mathrm{kg}$ x (PUTS) Production Age of Oil Palm Plantations. (2) Production of Oil Palm Planting Age (PUTS) $=($ PRUTKS $)$ Production of Oil Palm Planting Age X (UTKSI) Oil Palm Planting Age since Obtaining Oil Palm Plantation concession Permit. With the using formula above, we can determine the Production Value of Oil Palm based on the age of planting and the price of Fresh Fruit Bunches and are regressed as an independent variable to the dependent variable, namely dummy Oil Palm Expansion per pixel (1 pixel = $1000 \mathrm{ha}$ ).

\subsection{Effect of oil Palm Plantation}

Production on oil palm plantation expansion.

The estimation results of the probit panel model, the results of each increase in Palm Oil Production Value are caused by the increase in the price of Fresh Fruit Bunches (TBS) and Palm Oil Production Age (PUTS) of 0.192 with a significance level above $99 \%$. 
Table 9. Marginal Effect

Effect of Palm Production on Oil Palm Plantation Expansion for land use

\begin{tabular}{cc}
\hline VARIABLES & $\begin{array}{c}\text { Marginal Effect at } \\
\text { Means }\end{array}$ \\
\hline $\begin{array}{l}\text { Palm Oil Production Value } \\
\text { (in IDR Million) }\end{array}$ & $\begin{array}{c}0.00163^{* * *} \\
(0.0002097)\end{array}$ \\
Number of observations & 132.420 \\
Pixel & 13,242 \\
$\quad$ Number of cell code & \\
\hline Standard errors in parentheses & \\
$* * * \mathrm{p}<0.01, * * \mathrm{p}<0.05, * \mathrm{p}<0.1$ &
\end{tabular}

The results of analysis of the data drawn predictions, if the price of fresh fruit bunches (TBS) increases (1 in IDR), When, we are assuming a fixed quantity of farmers will tend to expand new land clearing for oil palm plantations.

For example: (1) Analysis of the Long Ikis subdistrict Paser Regency of East Kalimantan in Indonesia, with a prediction value of the likelihood of land expansion that is 0.0347 , the community will expand the expansion of oil palm land by $(0.0347 \times 1000$ ha $)=34.7$ hectares, then the average income of the community will increase around 6.942 million (in IDR) per hectare per oil palm harvest. (2) Analysis of the Muara Bengkal sub-district East Kutai Regency of East Kalimantan in Indonesia, with the Prediction Percentage Value of Possible Expansion of 0.0269 , the community will expand the expansion of oil palm land by $(0.0269 \times 1000$ ha $=26.9$ hectares), then the average income of the community will increase by around 5.371 million (in IDR) per hectare every palm oil harvest. (3) Analysis of the Sambaliung sub-district Berau Regency of East Kalimantan in Indonesia, with the Prediction Percentage Value of Possible Expansion of 0.0284 , the community will expand the expansion of oil palm land by $(0.0284 \times 1000$ ha $=28.4$ hectares $)$, then the average income of the community will increase by around 5.68 million (in IDR per hectare per oil palm harvest.
The probit marginal effect estimation results are done probit panel predictions which are Predictions Percentage of Likelihood of Land Expansion as:

The Prediction of Percentage of Land Expansion Possible $=0.00163 X$ Production Value of Palm Oil (in IDR Million)

The Prediction of the Percentage of Possible Land Expansion is then used as an independent variable to see how much the Percentage of Possibility of Land Expansion with Household Income. Household income data is obtained from the SUSENAS (Survey of National Statistical office) consumption module data by calculating the average household consumption in each region of the sub district administration code in the merge to each pixel with the identity of the sub district administration code and the district administration code which is the same as the SUSENAS code. SUSENAS Data Period 2001 - 2011, for each household is calculated spatially based on the classification of regional administration in each district and district in East Kalimantan Province. This consumption data is aggregate or the total consumption of all households. After the merge, it will be regressed using the panel regression approach as shown in the table 10 below:

Table 10. Model (3). Effect of Addition of Oil Palm Land to Average Revenue Households Period 2000 - 2011.

\begin{tabular}{lc}
\hline VARIABLES & $\begin{array}{c}\text { Average Household } \\
\text { Income per year }\end{array}$ \\
\hline $\begin{array}{l}\text { Prediction of Percentage of } \\
\text { Likelihood of } \quad \text { Land }\end{array}$ & $6.554 * * *$ \\
Expansion & $(1.162)$ \\
A constant & $15.46 * * *$ \\
& $(0.0353)$ \\
Observations & 13,420 \\
Number of cell code & 13,242 \\
\hline
\end{tabular}

Robust standard errors in parentheses $* * * \mathrm{p}<0.01, * * \mathrm{p}<0.05, * \mathrm{p}<0.1$

What should be noted in the interpretation of the equation above, the dependent variable is Household Income in the natural logarithm (ln) household income for one year (income = household consumption at SUSENAS x 12 
months). Why use (In) to get a better standard error than using data level (Million in IDR). So it can be interpreted that an increase in the prediction of the possibility of oil palm plantation expansion of $1 \%(0-100 \%)$ significantly above 99\% will increase the increase in the percentage of household income that has oil palm for one year by $6.54(654 \%)$ times income during the observation period.

\subsection{The Findings of Research and Policy Implications}

The Findings of research.

The findings of this study are in 2 (two) groups namely:

(1) Theoretically and empirically, and

(2) The policy implications in research activities.

By conducting the Ramsey test to test the specification error in the model, the test results are as follows:

\section{Ramsey RESET test using powers of the fitted values of palmplanta.}

\section{Ho: model has no omitted variables}

$$
\begin{array}{cr}
F(3,119169)= & 1865,42 \\
\text { Prob }>F= & 0.0000
\end{array}
$$

The results of the Ramsey test above it can be concluded that the regression model does not experience specification errors in the model with the resulting probability value (Prob) $0<0.05$.

The furthermore, the normality test needs to be done, for this test we can see the Normal Graph Normal P-Plot and see the Skewness / Kurtosis test, as well as the Shapiro-wilk test normality. As shown in Fig: 5.

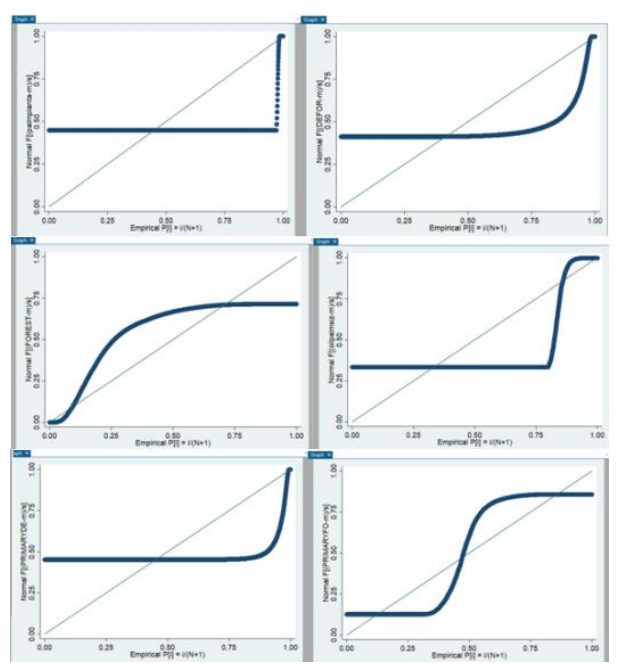

Fig (5). : The Normal graphs of P-Plots on Variables: palmplanta, DEFOR, FOR, PPSz.

The chart following the normal P-Plot line indicates the distribution of the residual data of the five variables is not normal because the plotting points do not follow the diagonal line and slightly out of the diagonal line, so it is difficult to say the data is normal or not. For this reason, we need to test skewness and kurtosis and shapirowilk normality in table 11 .

Table 11. Skewness/kurtosis test \& shapiro-

\begin{tabular}{|c|c|c|c|c|c|}
\hline 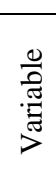 & ô & 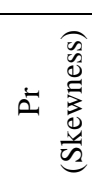 & 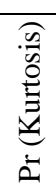 & 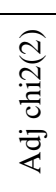 & 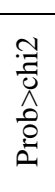 \\
\hline 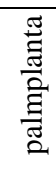 & $\begin{array}{l}\text { ఫิ } \\
\text { d్ }\end{array}$ & $\begin{array}{l}8 \\
0 \\
0 \\
0\end{array}$ & $\begin{array}{l}8 \\
0 \\
0 \\
0\end{array}$ & & \\
\hline $\begin{array}{l}\text { 总 } \\
\text { 囸 }\end{array}$ & 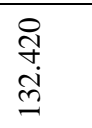 & $\begin{array}{l}8 \\
0 \\
0\end{array}$ & $\begin{array}{l}8 \\
\vdots \\
0\end{array}$ & . & . \\
\hline 串 & 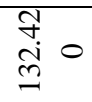 & $\begin{array}{l} \\
\\
0\end{array}$ & $\begin{array}{l} \\
\\
0\end{array}$ & . & . \\
\hline $\begin{array}{l}\hat{n} \\
\hat{n}\end{array}$ & 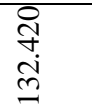 & \&. & : & . & . \\
\hline
\end{tabular}
wilk normality test.

.swilk palmplanta DEFOR FOR \& PPSz

Shapiro-wilk w test for normal data 


\begin{tabular}{|c|c|c|c|c|c|}
\hline 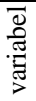 & : & 3 & $>$ & $N$ & $\begin{array}{l}\hat{N} \\
\hat{0} \\
0\end{array}$ \\
\hline 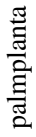 & 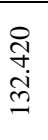 & 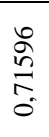 & $\begin{array}{l} \pm \\
0 \\
+ \\
0 \\
0 \\
-\end{array}$ & 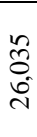 & $\begin{array}{l}8 \\
8 \\
8 \\
0\end{array}$ \\
\hline 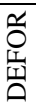 & 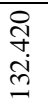 & 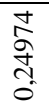 & $\begin{array}{c}0 \\
\\
+ \\
0 \\
\infty \\
i\end{array}$ & $\begin{array}{l}\text { lo } \\
\stackrel{0}{0} \\
\infty \\
i\end{array}$ & $\begin{array}{l}8 \\
\vdots \\
\vdots \\
0\end{array}$ \\
\hline 告 & 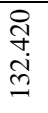 & $\begin{array}{l}\text { d } \\
\text { dे } \\
0 \\
0\end{array}$ & $\begin{array}{l}0 \\
0 \\
+ \\
0 \\
\\
-1\end{array}$ & 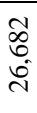 & $\begin{array}{l}8 \\
8 \\
8 \\
0 \\
0\end{array}$ \\
\hline $\begin{array}{l}\text { Nे } \\
\hat{2}\end{array}$ & 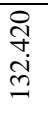 & 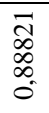 & 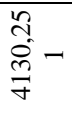 & $\begin{array}{l}\stackrel{m}{\forall} \\
\stackrel{d}{d}\end{array}$ & $\begin{array}{l}8 \\
8 \\
8 \\
0 \\
0\end{array}$ \\
\hline
\end{tabular}

Note: The normal approximation to the sampling distribution of $W^{\prime}$ is valid for $4<=n<=2000$.

The skewness and kurtosis test in table 10. for all Palmplanta (land use), DEFOR, FOR and PPSz variables, have a probability $<0.05$ so that all the variables can be agreed to be up normal, while the test results are in accordance with the P-Plot Graph in Fig : 5, and the distribution of the residual data on the variable variables in all the data is not normal because mapping the points does not take the direction of the diagonal line and slightly out of the diagonal line.

\subsection{Multicollinearity test.}

\section{Multicollinearity test can be done by:}

Multicollinearity test using VIF and compared to tolerance, where the results of the analysis are shown in table 4.20 , clearly visible VIF value < 5 , while tolerance values are al $1>0.20$, so it can be concluded that there is no multicollinearity problem in the multiple regression model.

Table. 12. Multicollinearity test of multiple regression models

\begin{tabular}{|l|c|c|}
\hline Variable & VIF & $\begin{array}{c}1 / \text { VIF } \\
\text { (tolerance) }\end{array}$ \\
\hline FOR & 1,35 & 0,740779 \\
\hline PPSz & 1,10 & 0,908754 \\
\hline DEFOR & 1,07 & 0,938158 \\
\hline Mean VIF & 1,19 & \\
\hline
\end{tabular}

Source: Data processed (2017).

\subsection{Homoscedasticity assumption test.}

It can be concluded in the analysis of this study that the data used in this study are not normal, to test the problem of heterokedasticity, then this study applies the Quantile Regression Test for how to overcome it.

It's this happens due to abnormalities from the previous data, and the solution is to transform the data by conducting a Quantile Regression Test.

\subsection{Quantile Regression Test.}

Tabel .13. Regresi Quantile palmplanta DEFOR FOR PPSz Test

\begin{tabular}{|c|c|c|c|c|c|c|}
\hline 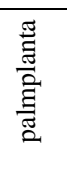 & Coef & 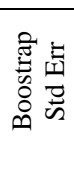 & $\mathrm{t}$ & $\begin{array}{l}P>1 \\
t 1\end{array}$ & \multicolumn{2}{|c|}{ 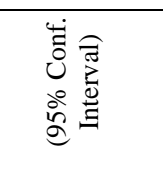 } \\
\hline 20 & & & & & & \\
\hline 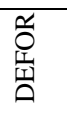 & $\begin{array}{l}\text { के } \\
8 \\
8\end{array}$ & $\begin{array}{l}\overline{0} \\
\stackrel{0}{0} \\
0 \\
0 \\
0\end{array}$ & $\stackrel{0}{8}$ & 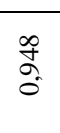 & $\begin{array}{l}\infty \\
\stackrel{0}{a} \\
\underline{i} \\
1\end{array}$ & $\begin{array}{l}\vec{F} \\
\infty \\
0 \\
0 \\
0\end{array}$ \\
\hline 号 & 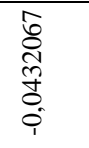 & 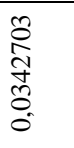 & 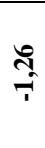 & $\begin{array}{c}\text { ì } \\
\text { on }\end{array}$ & $\begin{array}{l}\stackrel{2}{2} \\
\hat{0} \\
0 \\
\vdots \\
0 \\
1\end{array}$ & $\begin{array}{l}\text { ते } \\
\text { ठे } \\
\text { ठे. } \\
0\end{array}$ \\
\hline $\begin{array}{l}\hat{N} \\
\hat{\tilde{\alpha}}\end{array}$ & $\begin{array}{l}\mathbb{\pi} \\
\tilde{\Xi} \\
0 \\
0\end{array}$ & 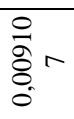 & $\underset{\sim}{ \pm}$ & $\begin{array}{l}\frac{n}{0} \\
0 \\
0\end{array}$ & 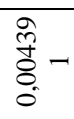 & $\begin{array}{l}\text { ठे } \\
\text { +े } \\
\text { ठ }\end{array}$ \\
\hline $\begin{array}{l}n \\
\tilde{\sigma}_{1}\end{array}$ & $\begin{array}{l}\text { ते } \\
\text { ర్ర } \\
\infty \\
\infty\end{array}$ & 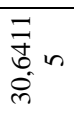 & ঙี & 啇 & $\begin{array}{l}\hat{\sigma} \\
\stackrel{T}{*} \\
\vec{T}\end{array}$ & $\begin{array}{l}0 \\
\infty \\
0 \\
\infty \\
\infty \\
\infty\end{array}$ \\
\hline
\end{tabular}

Simultaneous quantile regression No obs $=119.178$ bootstrap (90) SEs .90 Pseudo R2 =0,0091

Source : Data processed (2017).

We were looked in table 11, it turns out that there are 2 (two) variables namely PPSz value of $\mathrm{P}$ $(0.015)$, it is necessary to transform into the square root with the variable by making; model.g sqPPSz $=$ sqrt (PPSz).

Tabel 14. Simultaneous Quantile Regression palmplanta sqPPSz Test

.9 Quantile regression No of obs $=119.178$

\begin{tabular}{|c|c|c|c|c|c|c|}
\hline 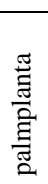 & 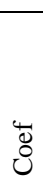 & 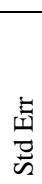 & - & $\underset{\hat{\Omega}}{\Xi}$ & $\cong$ & \\
\hline $\begin{array}{l}\hat{N} \\
\hat{\tilde{n}} \\
\frac{\tilde{n}}{1}\end{array}$ & $\begin{array}{l}\tilde{2} \\
\infty \\
\infty \\
\infty \\
\text { స్ } \\
-1\end{array}$ & $\begin{array}{l}\hat{\alpha} \\
\text { है }\end{array}$ & $\begin{array}{l}= \\
\text { त }\end{array}$ & 8 & 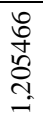 & 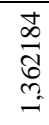 \\
\hline$\tilde{\Xi}_{1}^{0}$ & 0 & $\begin{array}{l}\text { aे } \\
\text { ปे } \\
\infty \\
\dot{J}\end{array}$ & 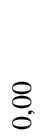 & $\stackrel{8}{8}$ & 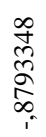 & 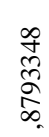 \\
\hline
\end{tabular}

Source : Data processed (2017). 
If the normality test is done with the Simultaneous Quantile regression test, which produces a probability value > 0.05 as shown in table 14 . Heterodaskesity test results with Simultaneous Quantile Regression tests apparently in the PPSz variable there is still heterodaskesitas so it needs to be transformed into a Log Transformation (logPPSz) as shown in table 15 . The results of tests with quantile regression so that heterokedastasis problems can be overcome as shown in table 15.

Tabel 15. Uji Quantile Regression palmplanta logPPSz.greg palmplanta logPPSz, quantile (90)

\begin{tabular}{|c|c|c|c|c|c|c|}
\hline 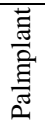 & ن & $\frac{5}{\overrightarrow{5}}$ & - & $\begin{array}{l}\Xi \\
\hat{a}\end{array}$ & \multicolumn{2}{|c|}{ 离彦离 } \\
\hline $\begin{array}{l}N \\
n \\
\hat{n}_{00} \\
0 \\
0\end{array}$ & 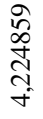 & \begin{tabular}{l}
$\infty$ \\
$\stackrel{2}{2}$ \\
$\hat{\delta}$ \\
$\stackrel{\delta}{0}$ \\
\multirow{+}{*}{}
\end{tabular} & $\underset{-}{\mathbb{S}}$ & $\begin{array}{l}\text { సे } \\
\text { o }\end{array}$ & $\begin{array}{l}\frac{8}{0} \\
\frac{n}{n} \\
i\end{array}$ & 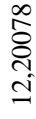 \\
\hline$\tilde{\delta}_{1}$ & $\begin{array}{l}\stackrel{m}{\tilde{\sigma}} \\
\underset{\sim}{+}\end{array}$ & $\begin{array}{l}\text { v } \\
\text { Jे } \\
\text { d }\end{array}$ & 궁 & $\begin{array}{l}\widetilde{0} \\
\infty \\
0\end{array}$ & 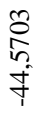 & 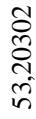 \\
\hline
\end{tabular}

Source : Data processed (2017).

When we are after transforming the value of the LogPPSz variable the data becomes normal because the PPSz value (1.04) or the value of P > 0.05 so that it is free from heteroscedasticity problems.

\subsection{Comparison of Research and Results.}

The findings of this research can be grouped into two aspects namely; first the theoretical aspects which include formulation, model specifications, identification of variables, economics and methodology, secondly the empirical aspects which include the use of data and application models, using empirical data.

The results of land use research from the results of a joint test (land use) for oil palm plantations are also proven and significant to forestry land (FOR), deforestation (DEFOR) (deforestation / land clearing), oil palm production (PPSz), then land use conversion increase for oil palm plantations in East Kalimantan Province during the study period
2000-2011, it would be more interesting if examined by subsequent researchers.

This study has a difference (uniqueness) with other studies as follows:

1) This study uses data processed with the Geo Spatial Information Contex Model processed by the Quantum Geo Informatic System (QGIS) application based on a digitized map with pixel size combined with the Stata MP.15, application, so the accuracy of the results is very significant in the analysis.

2) This study uses the OLS (Ordinary Least Square) Regression which was developed from the David Wheler, Dan Hammer, Robin Kraft, Susmita Dasgupta, and Brian Blankespoor (2011), and Okon.U models, E. C. Okorji.EC) (2014), and Models from Irwin E.G \& Geoghegan. J (2016), and Tepe E, \& Guldmann J.M (2017), with the Spatial Model for Land Use with a modified multiple variable model, resulting in an empirical and unique model

3) Proxy of average income per farmer / month is obtained from the level of productivity of farmers / month multiplied by the price of fresh fruit bunches (FFB) at that time, so that the income per farmer / month is obtained.

4) Proxy of the selling price of fresh fruit bunches (FFB) also affects the coefficient value on the expansion / desire to open new land for oil palm plantations in each district in East Kalimantan Province.

5) Proxy of oil palm plantations also influences forestry land deforestation so it affects land use.

6) Proxy of oil palm plantations has a negative effect on the use of forestry land (For) so that it affects the land use (land use).

7) This study has a very large degree of freedom that is 132,420 , because it uses panel data and cross sections, with pixel data 132,420, in East Kalimantan Province, and times series data for a period of time between 2000 and 2011 .

The results of the analysis above, it can be done by testing the model and by meeting the 
requirements of econometrics and economic theory, so that this research has strength in its test results (test strength) and has theoretically meaningful. The empirical aspects of this study are unique as follows:

1) Empirical data used are ex-post facto; the data that have occurred are implemented on the equation model in accordance with the main conditions in producing theoretical concepts so that the test results are true and real that can draw conclusions from the results that occur.

2) The Estimation results from using the OLS (Ordinary Least Square) Regression developed from the David Wheler, Dan Hammer, Robin Kraft, Susmita Dasgupta, and Brian Blankespoor (2011), \& Okon. U, E. C. Okorji.EC) (2014), which affects Palmplanta or land use, as well as the spatial model of the Irwin E.G \& Geoghegan, Model. J (2016), and Tepe E, \& Guldmann JM (2017), with Spatial Models elaborated/developed \& analyzed stata, so that an influence was found during the period 2000 to 2011. Palmplanta has a positive and significant effect on prod_val_jt (production) and influence the test of variables, as well as land use and increase in income of oil palm farmers in East Kalimantan Province.

3) The Estimated results with joint intersect to measure land use, so that there are points that can be measured Geo Spatial Information Contex Model of East Kalimantan Province (2017), with the Quantum Geo Information System (QGIS) application that produces points with pixel size. Each point / pixel with a size of 1,000 hectares will facilitate the measurement of the occurrence of willingnes to expan if an increase in commodity prices of fresh fruit bunches (TBS).

4) The results of this study also use the matrix of results of data processing with the Contex Model Geo Spatial Information, the results of data processing to intersect for land use so that changes are visible and significant from 2000 to 2011. After the policy of controlling oil palm plantation permits until now. no new licenses (moratorium) were issued either from the Provincial Government of East Kalimantan or from the Central Government, then the data was processed using the Stata application

5) Estimation results from the model are the production of each in 65 sub-districts in East Kalimantan Province multiplied by the price of fresh fruit bunches (FFB) where significant income is found, significantly above 99\%, which increases the percentage of household income that owns land oil palm for one year amounted to 6.54 (654\%) times the income during the observation period, this was very interesting and aroused community interest to open new plantations resulting in the conversion of land to oil palm plantations.

6) The results of the research test on the palmplanta land use model turned out to be very significant and positive for the test of all DEFOR (deforestation) variables, PPSz, although for the FOR (forestry land) variable test there were negative influences.

\section{Conclusion and policy.}

The results of analysis and discussion of land use and household income of oil palm plantations in East Kalimantan Province Indonesia can be explained as follows:

1. When It is the change of function of oil palm plantations in the Province of East Kalimantan in Indonesia is affected by:

a).Deforestation has a positive and significant to relationship.

Deforestation is not only for oil palm land but is caused by other lands outside the analysis of this study.

According to the survey on the field, this deforestation is caused by forest land being non-forest caused by mining concessions.

b). The forest land in East Kalimantan has significantly decreased due to the expansion of oil palm plantations. This can be seen from the negative relationship between forest land and oil palm plantations.

2. It's the increasing the use of land planted with oil palm plantations has a positive and 
significant effect in increasing the average income of the people in East Kalimantan;

3. Diversification policy for oil palm plantations with intercropped crops such as; palm sugar which is environmentally friendly and can store water content as a controller of ground water resources, this also greatly supports other income (Off farm) from farmers.

4. The land use, when in the transfer of land functions, such as rubber, cocoa plantations, dry paddy fields and other lands that are converted into oil palm plantations, so the government needs to make clear and firm regulations in order agricultural crop poly culture.

5. The existence of local regulations for oil palm investment to land supply at least 5 (five) percent of the area of the licensing land for other plants that are able to absorb water.

6. Forest land use control can be made effective by facilitating the management of land use permits for oil palm plantations, so that control over forest land use can be maintained and controlled. Forest land use control that does not pay attention to economic factors will negatively impact community income.

7. The production of palm oil derivatives can be processed into biodiesel, so the use of renewable energy from palm oil waste needs to be implemented and regulations regulated.

\section{Acknowledgements}

The authors are indebted to Padjadjaran University in particular the Faculty of Economics and Business, Padjadjaran University, Republic of Indonesia, and especially; Prof. Dr.S.Remi Sutyastie. MS, Wibowo K. SE. PhD and Yayan.S. SE. M.Si. Ph.D and all staff and Representation of Professor as well as Prof. Dr. Alisjahbana. A. SE. MA, from helpful comments, tools, discussion, and suggestions. The authors assume full responsibility for the remaining error.

\section{Reference}

1. Afri Awang. San (2016), "Moratorium dan Evaluasi Perijinan Perkebunan Kelapa
Sawit, 19 July 2016, Kementerian Lingkungan Hidup dan Kehutanan" , Dirjen Planologi Kehutanan dan Tata Lingkungan,. Badan Libang dan Inovasi Research, Development and Inovation Agency, Jakarta.

2. Ali, (2014), Pengertian polusi dan faktor penyebabnya, http://www.pengertianpakar. com/2014.

3. Arief Daryanto dan Yundy Hafizrianida, 2010" Model-model Kuantitatif untuk Perencaan Pembangunan Ekonomi Daerah; Konsep dan Aplikasi. Penerbit IPB Press Kampus IPB Taman Kencana Bogor.

4. Baltagi, Badi H. 2005. Econometric Analysis of Panel Data; Third edition. chippenham: Antony Rowe Ltd.

5. Barbier, Edward B. \& Burgess, J.C., 1997. "Economic analysis of tropical forest land use option, Land Economic 73(2),174-195, University Library of Munich, German.

6. Budiyanto, Eko, 2016, "Sistem Informasi Geografis dengan Quantum GIS", Penerbit CV. Andi Offset. Yogyakarta.

7. David Russel Y, Tahun 2000, "Sustainable Agriculture and Deforestation in the Peruvian Amazon". Michigan State University., East Lansing MI, USA. Yanggen, D.; @cgiar.org, asb;

8. David W, Hammer, Robin Kraft, Susmita Dasgupta, and Brian Blankespoor (2011) "Economic Dynamics and Forest Clearing" (A Spatial Econometric Analysis for Indonesia), CEFOR, December 2011.CGD Working Paper 280. Washington, D.C.: Center for Global Development.

http://www.cgdev.org/content/publications /detail/1425820.

9. Daryanto.A,2010,"Position of Agriculture Competitiveness in Indonesia and Its Efforts for Improvement", IPB Press. Bogor.

10. David Wheler, Dan Hammer, Robin Kraft, Susmita Dasgupta, and Brian Blankespoor, 
dalam penelitian ekonomi dan pembukaan lahan kehutanan Yang dipublikasikan melalui Center for Global Development dengan judul “ Economic Dynamics and Forest Clearing'; A Spatial Econometric Analysis for Indonesia", mempublikasi paper tersebut mengenai pembukaan lahan kehutanan didaerah Provinsi Riau dan Kalimantan dengan jangka waktu Tahun 2007 sampai dengan 2011.

11. Gasim Alwi, 1997, "Dampak keberadaan perkebunan kelapa sawit terhadap pendapatan rumah tangga petani dan pendapatan daerah Pemerintah Daerah Tingkat II Pasir, Masters in development economics, Gadjah Mada University, Yogyakarta.

12. Gujarati, Damodar N. 2004. Basic Econometrics, Fourth Edition. New York : The Mc. Grow-Hill Companies.

13. Greene. W.H, 2002" Econometric Analysis" Prentice Hall FIFTH EDITION" New York University, Copyright (C) 2003, 2000, 1997, 1993 by Pearson Education, Inc., Upper Saddle River, New Jersey, 07458. All rights reserved. Printed in the United States of America.

14. Greene. W.H, 2016 " Applied Econometrics, critical concepts economics" Edited by William W Greene. Henry Kaufman Management Center Department of Economics, 44 West Fourth Street, 7-90, New York, NY 10012, Email:wgreene@stern.nyu.edu

15. Hasna.O (2014), "PMDN, PMA and Labor Factors as the Indicators of the Success of Development in Province of Maluku: An Application of New Growth Theory", Faculty of Economics, Darussalam University, Ambon, Indonesia, Published: January 4, 2015 www.sciedu.ca/rwe, Research in World Economy Vol. 6, No. $1 ; 2015$.

16. Havrland,B and Yayan Satyakti (2011), "Renewable Energy Economics In Developving Countries", Institute of
Tropics and Subtropics, CZECH University Of Life Sciences Prague.

17. Husein Umar, 2003, Metodologi Penelitian Untuk Skripsi dan Tesis Bisnis,Jakarta : PT. Gramedia Pustaka

18. Husein Umar H (2009), Metode Penelitian untuk Skripsi dan Tesis Bisnis (Jakarta: PT. Raja Grafindo Persada, 2009).

19. Instruksi Presiden Republik Indonesia No 8 Tahun 2015 tentang Penundaan Pemberian Izin Baru dan Penyempurnaan Tata Kelola Hutan Alam Primer dan Lahan Gambut, sebagai kelanjutan dari Instruksi Presiden No 6 Tahun 2013 dan Instruksi Presiden No 10 Tahun 2011.

20. Irwin E.G \& Geoghegan. J (2016), Theory, data, methods: "Developing spatially explicit economic models of land use change ", Agriculture, Ecosystems and Environment $85 \quad$ (2001) 7-23, Agricultural, Environmental, and Development Economics, Ohio State University, 2120 Fyffe Rd., Columbus, $\mathrm{OH}$ 43210, USA, Department of Economics and George Perkins Marsh Institute, Clark University, 950 Main St., Worcester, MA 01760, USA.

21. Jayadinata J.T, Tata Guna Tanah dalam Perencanaan Pedesaan, Perkotaan, dan Wilayah, Penerbit ITB Bandung, Edisi ketiga Bandung, 1999.ISBN 979-9299-020 .

22. J. Pirker, Mosnier Aline, Kraxner F, Havlik, Obersteiner M, yang dipublikasikan di Jurnal Global Environmental Change (2016) https://www.journals. elsevier. com/global-environmental-change.

23. Kementerian Lingkungan Hidup dan Kehutanan, Dirjen Planologi kehutanan dan tata lingkungan, Prof.San Afri Awang. Badan Libang dan Inovasi Research, Development \& Inovation Agency, Jakarta, Moratorium dan Evaluasi Perijinan Perkebunan Kelapa Sawit, 19 July 2016. 
24. Khandker, Shahidur R.; Koolwal, Gayatri B.; Samad, Hussain A.. (2010). Handbook on Impact Evaluation : Quantitative Methods and Practices. World Bank, World Bank.

25. Kurrataa'yun (2012), "Kajian Lingkungan dan Pemetaan Potensi Sawit Sebagai Sumber Energi Terbarukan di Indonesia", By Agung Wijono, BPPT, Serpong. 2013.

26. Kusdarjito, C. 1995, "Pengaruh Keberadaan Inti Terhadap Pendapatan Petani, Studi Kasus PT. Mukarabi Buana Kecamatan Tempel Kabupaten Sleman Yogyakarta", Tesis, Universitas Gadjah Mada.

27. Latan, Hengky, 2014, "Äplikasi Analysis Data Statistik untuk Ilmu Sosial Sains dengan STATA", Penerbit Alfabeta, Bandung.

28. Muhadjir, Noeng. 1996. Metodologi Penelitian Kualitatif, Edisi Ketiga. Yogyakarta : Rekesarasin.

29. Myers, Jerome L dan Arnold D. Well. 2003. Research Design and Statistical Analysis, Second Edition. London: Lawrence Erlbaum Associates Publishers.

30. Nachrowi. D.N, Usman.H. (2006). "Pendekatan Populer dan Praktis Ekonomitrika, Untuk analisis Ekonomi dan Keuangan". Lembaga Penerbit Fakultas Ekonomi Universitas Indonesia.

31. Okon.U e,E. C. Okorji.EC.(2014), "Economic analysis of raphia palm (raphia spp.)wine production in akwa ibom state, Nigeria", International Journal of Agriculture and Crop Sciences. Available online at www.ijagcs.com IJACS/2014/76/347-352 ISSN 2227-670X @2014 IJACS Journal.

32. Osemwegie Q.E. Anyiwe.M.A.2 and Odewale. J.O,(2016)," Econometric Analysis of the Economic Cost of Lethal Yellowing Disease (LYD) on Coconut (Cocos nucifera L.) Yield in LYD Epidemic Area of Nigeria: A Case Study of Nigerian Institute for Oil Palm Research
(NIFOR)", Benin City, Edo State, Nigeria. American Journal of Experimental Agriculture 11(5): 1-10, 2016, Article no.AJEA.24003 ISSN: 2231-0606.

33. Parkin, M. and Robin Bade, 1992, Macroeconomic, Second Edition, Prentice Hall, Englewood Cliffs, New Jersey

34. Perman, R, Yue Ma, McGilvray J. Common.M, (2003).'Natural Resource and Environmental Economics", Pearson Addison Wesley, Pearson Education Limited, Edinburgh Gate Harlow Essex CM202JE and Associated Companies, Third edition 2003 Pearson Education Limited.

35. Perda.No.07 Tahun 2014, Tentang Rencana Pembangunan Jangka Menengah Daerah Provinsi Kalimantan Timur Tahun 2013-2018, Diperbanyak Oleh Bappeda Prov Kaltim 2014, Hal II-21-49.

36. Peraturan Menteri lingkungan hidup dan kehutanan seperti No. P.31/MenhutII/2014 tentang IUP (IUPHHK -HA), (IUP HH TK), (IUP HH Hutan Kayu - Restorasi Ekosistem Dalam Hutan), (IUP HH Hasil Hutan Bukan Kayu Bukan Dalam Hutan Alam dan Hutan Tanaman Industri dan lainnya).

37. Peraturan Menteri Lingkungan Hidup dan Kehutanan Republik Indonesia, No.P.51/Menlhk/Setjen/ KUM.1/6/2016 Tanggal 19 Juli 2016, Tentang Tata Cara Pelepasan Kawasan Hutan Produksi Yang Dapat Dikonversi..

38. Prashasta, Edy, 2013, "Mengelola Peta dijital, Mendapatkan \& Mengelola Peta Dijital Penting \& Gratis di Internet". Penerbit Informatika Bandung.

39. Reungsri, Thanapat (2010) "The Impact Of Public Infrastructure Investment On Economic Growth In Thailand", Victoria University.

40. Romer, David. (2012). Advanced Macroeconomics, Fourth Edition. Berkeley: The McGraw-Hill Irwin. ISBN 978-0-07-351137-5. 
41. Rudiantho J. Saragih (2013) Socioeconomic and Ecological Dimension of Certified and Conventional Arabica Coffee Production in North Sumatra, Indonesia, ISSN (E): 2224-4433 Volume 3 No. 3 March 2013 Asian Journal of Agriculture and Rural Development, Vol. 3, No. Graw-Hill Companies, Inc All right reserved. Bahasa Ind 3, pp. 93-107.

42. Samuelson, Paul A dan Nordhaus, William D. 1995. Makro Ekonomi. IKAPI Jakarta.

43. Sodik J \& Nuryadin D. 2005, Investasi dan Pertumbuhan Ekonomi Regional (Studi Kasus Pada 26 Propinsi di Indonesia, Pra dan Pasca Otonomi), Jurnal Ekonomi Pembangunan, Kajian Ekonomi Negara Berkembang Hal.157170, UPN "Veteran" Yogyakarta, Indonesia.

44. Solow R.M., by Aghion Philippe and Peter Howitt, "Endogenous Growth Theory", Department Of Economic Massachusetts Institute of Technology, Problem and solution by Cecilia Garcia- Penalosa , Coodinated by Maxime Brant-collett, MIT Press Cambridge 1998, Massachusetts, London, England, ISBN 0262-01166-2 (alk,paper): HD45.A47, 1998, 338.9-dc21.97-29036.

45. Sugiyanto.C (2011), The impact of trade liberalization on the Indonesian palm oil and coconut oil markets", Submitted in partial fulfillment of the requirements for the degree of Doctor of Philosophy in Agricultural Economics in the Graduate College of the University of Illinois at Urbana-Champaign, 2002, UMI Number: 3044234, ProQuest Information and Learning Company 300 North Zeeb Road P.O. Box 1346.Ann Arbor, Ml 481061346.

46. Sugiarto, Herlambang. T, Brastoro, Sudjana. R, Kelana.S. (2002), Ekonomi Mikro, Sebuah Kajian Komprehensif, Penerbit PT Gramedia Pustaka Utama, Jakarta.
47. Shri Dewi A/P Applanaidu Fatimah Mohamed, Mad Nasir Shamsudin Arshad Amna Awad Abdel Hameed (2011). An Econometric Analysis of the Link between Biodiesel Demand and Malaysian Palm Oil Market. International Journal of Business and Management, Vol. 6, No. 2; February 2011, www.ccsenet.org/ijbm.

48. The Department of Forestry and East Kalimantan Forestry Service, Land Use Map, East Kalimantan Province 2014.

49. East Kalimantan Province Mining Office, 2013 East Kalimantan Province Mining Data in 2013.

50. The East Kalimantan Province Plantation Service (2016 and 2017) Average Production of Palm Oil Based on Age of Plants in East Kalimantan Province.

51. Tepe E, \& Guldmann J.M (2017). "Developing spatially explicit economic models of land use change ",Computers, Environment and Urban Systems, Department of City and Regional Planning, Cankaya University, Cankaya, 06530 Ankara, Turkey, Department of City and Regional Planning, The Ohio State University, Columbus, OH 43210, USA. journal home page: www.elsevier.com/locate/ceus..

Environment and Urban Systems 64 (2017) 204-214.

52. The Central Statistics Agency of East Kalimantan Indonesia: The East Kalimantan in Figures for the Year 2010, 2013 - 2017

53. The East Kalimantan Province planning and development agency: "strategic environmental assessment of East Kalimantan Province (2014-2018).

54. The Central Kalimantan Statistics Agency of East Kalimantan, Indonesia: The East Kalimantan Province Agriculture Census, Indonesian 2013.

55. Tobing PL, 1998, Kajian awal penerapan sistem pengelolaan lingkungan ISO seri 14000 di perkebunan kelapa sawit, Warta 
Pusat Penelitian Kelapa Sawit. (Hal 121126).

56. Tarmisol, Universitas Gadjah Mada (Jurnal) 2012, "Efisiensi Produksi dan Penetapan Umur Ekonomis Usaha Tani Kelapa Sawit di Kalimantan Timur".

57. Ukaro Ofuoku A.dan okeleke chukwuji. C (2012), "The impact of rural-urban migration on plantation agriculture in the niger delta region, Nigeria", delta state university, asaba campus, nigeria, Journal of Rural Social Sciences, 27(1), 2012, pp. 137-151. Copyright (C) by the Southern Rural Sociological Association,

58. Widarjono, A. 2005. Ekonometrika Teori dan Aplikasi untuk Ekonomi dan Bisnis. Ekonisia. Yogyakarta

59. Yanggen. D.R (2000), "Sustainable Agriculture And Deforestation In The Peruvian Amazon", Michigan State University Umi Number: 3000638, Bell \& Howell Information And Learning Company 300 North Zeeb Road P.O. Box 1346 Ann Arbor, Ml 48106-1346. 